\title{
"All bad things must come to an end": the application of state aid rules to the new EU regime for bank resolution
}

Citation for published version (APA):

Nicolaides, P. (2015). "All bad things must come to an end": the application of state aid rules to the new EU regime for bank resolution. Maastricht University. https://doi.org/10.26481/spe.20151203pn

Document status and date:

Published: 03/12/2015

DOI:

10.26481/spe.20151203pn

Document Version:

Publisher's PDF, also known as Version of record

\section{Please check the document version of this publication:}

- A submitted manuscript is the version of the article upon submission and before peer-review. There can be important differences between the submitted version and the official published version of record.

People interested in the research are advised to contact the author for the final version of the publication, or visit the DOI to the publisher's website.

- The final author version and the galley proof are versions of the publication after peer review.

- The final published version features the final layout of the paper including the volume, issue and page numbers.

Link to publication

\footnotetext{
General rights rights.

- You may freely distribute the URL identifying the publication in the public portal. please follow below link for the End User Agreement:

www.umlib.nl/taverne-license

Take down policy

If you believe that this document breaches copyright please contact us at:

repository@maastrichtuniversity.nl

providing details and we will investigate your claim.
}

Copyright and moral rights for the publications made accessible in the public portal are retained by the authors and/or other copyright owners and it is a condition of accessing publications that users recognise and abide by the legal requirements associated with these

- Users may download and print one copy of any publication from the public portal for the purpose of private study or research.

- You may not further distribute the material or use it for any profit-making activity or commercial gain

If the publication is distributed under the terms of Article $25 \mathrm{fa}$ of the Dutch Copyright Act, indicated by the "Taverne" license above, 


\section{Maastricht University}

Prof. dr. Phedon Nicolaides

Faculteit der Rechtsgeleerdheid

"All Bad Things Must Come

to an End":

The Application of State Aid

Rules to the New EU Regime

for Bank Resolution 


\title{
Mastricht University
}

13 February 2016

\section{"All Bad Things Must Come to an End":}

The Application of State Aid Rules to the New EU Regime for Bank Resolution ${ }^{1}$

\author{
Phedon Nicolaides ${ }^{2,3}$
}

\footnotetext{
${ }^{1}$ This is an expanded and revised version of the inaugural lecture I delivered on 3 December 2015 at the University of Maastricht. The quotation "all bad things must come to an end" is from the tv series Breaking Bad.

${ }^{2}$ Professor at the University of Maastricht and the College of Europe, Bruges.

${ }^{3}$ I would like to thank Gibran Watfe and an anonymous referee for comments on an earlier draft.
} 


\section{Introduction}

There is a burgeoning literature on the financial crisis. The topics examined by most of this literature fall in three categories: i) the causes of the crisis and the new EU institutions that have been set up in response, ii) the rights and obligations of Eurozone members and the support that has been provided by some Member States to other Member States, and iii) the state aid that has been granted to banks and other financial institutions.

As of 1 January 2016, the Single Resolution Mechanism [SRM] has become fully operational. The purpose of the SRM, as laid down by Regulation $806 / 2014^{4}$ is to ensure the orderly restructuring of banks which would otherwise fail. Orderly restructuring and, if necessary, closure of banks, are intended to prevent the collapse of any bank from affecting the whole financial system. The SRM also aims to protect taxpayers by forcing shareholders and creditors of banks to be bailed in first before any public money is used to shore up ailing banks.

The SRM is the counterpart to the Single Supervisory Mechanism which confers supervisory tasks to the European Central Bank. Both apply to Eurozone countries and any other Member State that wishes to participate. The SRM Regulation is accompanied by Directive $2014 / 59^{5}$ on the recovery and resolution of banks [or BRRD] that applies to all Member States and requires them to establish national resolution authorities.

The SRM and BRRD in effect mean that as of 1 January 2016, state aid will only be an option of last resort when a bank gets into trouble and needs external support. This is because the Single Resolution Board, which has also been established by the SRM Regulation, and the national resolution authorities will first have to ask shareholders, creditors and other private investors to contribute before turning to the Single Resolution Fund [SRF] and the national resolution funds [NRF]. Taxpayers' money will be used only if the private contributions and the support from the SRF and NRF prove to be insufficient. But then if all this money is not enough, it may be that the bank cannot become viable again and therefore it will have to be closed down. This is another reason why state aid will become rare in the banking sector. Not only will shareholders and creditors be bailed in first, but also banks will be allowed to fail, probably more often than in the past. Bank closure will be more frequent or a more realistic option because the SRM and BRRD will aim to separate the sustainable from the unsustainable operations of ailing banks so as to contain any negative impact on the rest of the financial system. Once systemic failure is controlled, the unviable bank can be allowed to close down.

\footnotetext{
${ }^{4}$ Regulation 806/2014/EC of the European Parliament and of the Council of 15 July 2014 establishing uniform rules and a uniform procedure for the resolution of credit institutions and certain investment firms in the framework of a Single Resolution Mechanism and a Single Resolution Fund and amending Regulation (EU) No 1093/2010, [2014] OJ L 225/1.

${ }^{5}$ Directive 2014/59/EU of the European Parliament and of the Council of 15 May 2014 establishing a framework for the recovery and resolution of credit institutions and investment firms and amending Council Directive 82/891/EEC, and Directives 2001/24/EC, 2002/47/EC, 2005/56/EC, 2007/36/EC, 2011/35/EU, 2012/30/EU and 2013/36/EU, and Regulations (EU) No 1093/2010 and (EU) No 648/2012, of the European Parliament and of the Council, [2014] OJ L 173/190.
} 
It should also be noted that, by ranking who gets bailed in, the SRM and BRRD, together with the rules on deposit guarantees, make bank runs very unlikely. This is because covered depositors [i.e. with deposits up to EUR 100,000] are excluded from bailing ins and are protected up to EUR 100,000.

Both the SRM Regulation and the BRRD have provisions on state aid. When a ministry of finance injects capital in a bank to rescue it, there is no doubt that it grants state aid. However, it is not so obvious why capital from the Single Resolution Fund or the national resolution funds would also be classified as state aid. First, the resources of the SRF and of the NRFs are contributed by banks themselves. Second, the Single Resolution Board that manages the SRF is not a national authority. It normally does not fall in the category of institutions covered by Article 107(1) TFEU. Third, any money that is injected in a bank by the SRF would normally be granted via a channel that is controlled by a national authority.

The purpose of this article is to examine the reasons and consequences of the application of state aid control to support from the SRF and to identify the likely differences between support from the SRF and from the NRFs.

The structure of the article is as follows. First, it reviews how state aid rules apply to banks and other financial institutions and how these rules have evolved. Second, it identifies the provisions the SRM Regulation and the BRRD that refer to state aid and considers how state aid rules and procedures may apply to bank resolution undertaken by the SRB or the national resolution authorities. Third, it examines several recent Commission decisions on bank resolution and assesses the views of the Commission why state aid rules should apply. Fourth, it draws a number of conclusions about the implications of applying state aid control and discipline to support granted both by national and EU institutions.

The main conclusion of the article is that, although it is surprising that state aid rules would apply to funding managed by EU institutions, state aid rules are likely to ensure equal treatment of Eurozone and non-Eurozone banks. However, the interjection of state aid compliance at the EU level will likely complicate authorisation procedures.

\section{State aid rules that apply to banks and other financial institutions}

There are several sets of state aid rules that may apply to banks. Which rules apply depends on when the measure was notified to the Commission by the Member State. The relevant rules and time periods are as follows.

\section{1) Before October 2008}

The Commission applied to banks the rules contained in the normal rescue \& restructuring guidelines. Indeed, despite the arguments of the UK to the contrary, the Commission refused to authorise state aid to Northern Rock - the first bank that had to be rescued when the crisis broke out - on the basis of Article 107(3)(b) [to remedy a serious disturbance in the economy of a Member State]. ${ }^{6}$ The normal rescue \& restructuring guidelines are based on Article 107(3)(c) [for the development of an economic activity].

\footnotetext{
${ }^{6}$ UK - NN 70/2007.
} 
2) Between 13 October 2008 and 31 July 2013

Soon after the outbreak of the financial crisis, the Commission adopted its first set of rules that applied specifically to financial institutions. The legal basis of these rules is Article 107(3)(b). The Banking Communication of October $2008^{7}$ was accompanied by other measures that were introduced in the period 2008-2009. In addition to the Banking Communication, there was the Recapitalisation Communication ${ }^{8}$, the Impaired Assets Communication $^{9}$, the Restructuring Communication, as well as the Prolongation Communication of $2010^{10}$ and of $2011^{11}$. The Commission also departed from its normal procedures by expediting the assessment of state aid to banks and determining its compatibility within a few days rather than a few months.

\section{3) Between 1 August 2013 and 31 December 2014}

The Commission adopted a new Banking Communication which came into effect on 1 August and continues to be in force..$^{12}$ It replaces the 2008 Banking Communication and supplements the remaining crisis rules (in particular the Recapitalisation Communication, the Impaired Assets Communication and the Restructuring Communication ${ }^{13}$ ). Most importantly, the 2013 rules introduced a more effective restructuring process for aided banks and strengthened burden-sharing requirements, asking shareholders and subordinated debt-holders to contribute before aid could be granted.

\section{4) Between 1 January 2015 and 31 December 2015}

According to the SRM Regulation and BRRD the default option for failing banks is to go into normal insolvency proceedings. Only if the competent resolution authority decides that it is in the public interest to do so, they can be resolved in line with the provisions of the BRRD. State aid to failing banks notified to the Commission after 1 January 2015 can only be granted if the bank is put into resolution, in compliance with the provisions of the BRRD in addition to EU state aid rules. The only exception is a so-called "precautionary recapitalisation", allowing state aid outside of resolution in narrowly defined circumstances [Article 32(4) of the BRRD and Article 18(4) of the SRM Regulation].

\section{5) From 1 January 2016}

\footnotetext{
${ }^{7}$ Communication from the Commission on the application of State aid rules to measures taken in relation to financial institutions in the context of the current global financial crisis, [2008] OJ C 270/8.

${ }^{8}$ Communication from the Commission on the recapitalisation of financial institutions in the current financial crisis: limitation of aid to the minimum necessary and safeguards against undue distortions of competition, [2009] OJ C 10/2.

${ }^{9}$ Communication from the Commission on the treatment of impaired assets in the Community banking sector, [2009] OJ C 72/1.

${ }^{10}$ Communication from the Commission on the application, from 1 January 2011, of State aid rules to support measures in favour of banks in the context of the financial crisis, [2010] OJ C 329/7.

${ }^{11}$ Communication from the Commission on the application, from 1 January 2012, of State aid rules to support measures in favour of banks in the context of the financial crisis, [2011] OJ C 356/7.

${ }^{12}$ Communication from the Commission on the application, from 1 August 2013, of State aid rules to support measures in favour of banks in the context of the financial crisis, [2013] OJ C 216/1.

${ }^{13}$ Commission communication on the return to viability and the assessment of restructuring measures in the financial sector in the current crisis under the State aid rules, [2009] OJ C 195/9.
} 
According to the BRRD, any state aid notified to the Commission that triggers resolution under the BRRD can only be approved subject to bail-in of at least $8 \%$ of the bank's total liabilities, which may require also converting senior debt and uncovered deposits.

The Commission has applied these rules with increasing strictness in about 450 decisions in the period 2008-2015. ${ }^{14}$ Initially, Member States were given much leeway to grant liquidity guarantees and inject fresh capital in banks. The banks themselves were allowed not to offer compensatory measures, as is normally the practice with the rescue and/or restructuring of companies in other sectors, because the value of their assets were depressed and forced sale would have been difficult and not have generated sufficient revenue. Gradually, however, the Commission imposed stricter requirements such as the full implementation of restructuring plans capable of restoring the long-term viability of the banks in question, withdrawal from non-core business and regions, adequate remuneration of public funds and behavioural restrictions on beneficiary banks with respect to the marking of their products and possible acquisition of other banks. ${ }^{15}$

The Commission had to strike a balance between preventing systemic failure and serious disturbance in the economy of a Member State, on the one hand, and preventing distortions to competition in the internal market, on the other. As the crisis abated and the prospect of serious disturbance declined, the rules have been tightened to prevent unnecessary distortions to competition.

Specifically with regard to resolution of banks, points 70-82 of the 2013 Banking Communication lay down s set of criteria that the Commission has used to determine the compatibility of any aid with the internal market:

1. Limitation of liquidation costs: Aid should enable the bank to be wound up in an orderly fashion, while limiting the amount of aid to the minimum necessary.

2. Limitation of distortions of competition: Aid should not result in undue distortion of competition.

3. Own contribution (burden-sharing): The bank [i.e. its owners or creditors] should bear a portion of the liquidation costs. In addition, the claims of shareholders and subordinated debt holders must not be transferred to any continuing economic activity.

4. Restoring long-term viability: The sale of an ailing bank to another financial institution can contribute to the restoration of long-term viability, if the purchaser is viable and capable of absorbing the transfer of the ailing bank.

Furthermore, section 6.3 of the 2013 Banking Communication, exclude the presence of aid to the purchaser if the sale is organised via an open and unconditional competitive tender and the assets are sold to the highest bidder.

\footnotetext{
${ }^{14}$ C. Quigley QC, European State Aid Law and Policy (3rd edition, Hart Publishing, 2015), p. 467.

${ }^{15}$ F.-C. Laprévote, M. Paron, 'The Commission's Decisional Practice on State Aid to Banks: An Update', 14 European State Aid Law Quarterly (2015), p. 88-116.

See also DG Competition's statistics on state aid to banks. They can be accessed at: http://ec.europa.eu/competition/state aid/scoreboard/financial economic crisis aid en.html See also the overview of ongoing investigations, which was updated in January 2016: http://ec.europa.eu/competition/recovery/banking case list public.pdf
} 
In summary, state aid is allowed only if:

1. The use of taxpayer money is limited through appropriate burden-sharing measures. This requires the bank, its owners and creditors to contribute to the cost of the bank failure before the taxpayer can be exposed to the risk of becoming part owner of a bank.

2. Banks undergo the necessary in-depth restructuring to return to long-term viability without further need for state support on the basis of a restructuring plan, or if this is not possible, they are wound down and exit the market in an orderly fashion.

3. Distortions of competition are limited through proportionate remedies. Since state aid distorts competition, as it gives the recipient bank an advantage over its competitors, it needs to be balanced out by ordering the bank to close or sell parts of their businesses or ensuring through behavioural constraints that it does not use the aid to undercut their competitors.

\section{The BRRD and SRM rules on financing of resolution}

In order to be effective, the resolution of a bank normally needs a certain amount of funding. For example, if the authorities create a "bridge" bank, it will need capital or short term loans to be able to operate. These costs are to be borne by the banking sector rather than taxpayers. ${ }^{16}$

For this reason, the BRRD requires every Member State to set up financing arrangements which are funded with contributions from banks and investment firms in proportion to their liabilities and risk profile. Banks contribute in relation to their share of specific liabilities of the total size of the national financial sector so that those who contribute most could potentially benefit most in case they enter resolution.

The national financing arrangements are funded ex-ante. Contributions are raised from banks annually over a 10 year period in order to reach a target funding level of at least $1 \%$ of covered deposits [i.e. deposits up to EUR 100,000].

Each national fund finances the resolution of the entities established in its own territory. For cross-border groups, the relevant national arrangements are required to contribute to a funding plan pre-agreed between the competent resolution authorities. If the ex-ante funds are insufficient to deal with the resolution of an institution, further contributions will be raised (ex post).

In case of need, national financing schemes are also able to borrow from one another. Other schemes can provide support unless they consider that such lending would for instance leave them without sufficient funds to deal with an imminent resolution action in their own national market.

Shareholders and creditors of the bank under resolution bear the cost of the bank failure in the first instance. Recapitalisation is to be financed primarily by these stakeholders. However, the BRRD and SRM provide that after these stakeholders have borne sufficient losses (i.e. $8 \%$ of the liabilities of the bank under resolution) through write-down or

\footnotetext{
${ }^{16}$ J. Armour, 'Crisis Management and Resolution', in N. Moloney, E. Ferran and J. Payne (eds.), The Oxford Handbook of Financial Regulation (Oxford University Press, 2014).
} 
conversion, in exceptional circumstances the resolution financing arrangement may bear remaining losses but only up to $5 \%$ of the bank's liabilities.

This restrictive approach is intended to be a remedy to the moral hazard that might arise with the creation of a large fund. These restrictions mean that in practice the main use of the resolution funds will be limited to, for example, providing loans to a bridge institution, purchasing specific assets of an institution under resolution, guarantee certain assets or liabilities of the institution under resolution, or in exceptional circumstances contributing to loss absorption by replacing creditors who would have been bailed in.

The main aim of bail-in is to stabilise a failing bank so that its essential services can continue, without the need for bail-out by public funds. The tool enables authorities to recapitalise a failing bank through the write-down of liabilities and/or their conversion to equity so that the bank can continue as a going concern. This would avoid disruption to the financial system that would likely be caused by stopping or interrupting the bank's critical services, and give the authorities time to reorganise the bank or wind down parts of its business in an orderly manner - an "open bank resolution". In the process, shareholders should be severely diluted or wiped out, and management be replaced. ${ }^{17}$

In a "closed bank resolution" the bank would be split in two, a good bank or bridge bank and a bad bank. The good bank-bridge bank is a newly created legal entity which continues to operate, while the old bad bank is liquidated. Bank creditors that are not systemic can either be left with the old bank and undergo losses as part of the liquidation or be transferred to the new bank either reducing their claims or converting them into equity.

Bail-in potentially applies to any liabilities of the institution not backed by assets or collateral. It does not apply to deposits protected by a deposit guarantee scheme, shortterm inter-bank lending or claims of clearing houses and payment and settlement systems (that have a remaining maturity of seven days), client assets, or liabilities such as salaries, pensions, or taxes. In exceptional circumstances, authorities can choose to exclude other liabilities on a case-by-case basis, if strictly necessary to ensure the continuity of critical services or to prevent widespread and disruptive contagion to other parts of the financial system, or if they cannot be bailed in in a reasonable timeframe.

The write down will follow the ordinary allocation of losses and ranking in insolvency. Equity has to absorb losses in full before any debt claim is subject to write-down. After shares and other similar instruments, it will first, if necessary, impose losses evenly on holders of subordinated debt and then evenly on senior debt-holders.

Deposits from SMEs and natural persons, including in excess of EUR 100,000, will be preferred over senior creditors. The deposit guarantee scheme to which the institution is affiliated (and the deposits it covers) will in turn rank above these. It will also be liable to assume losses for the amount that it would have had to bear if the bank had been wound up under normal insolvency proceedings.

\footnotetext{
${ }^{17}$ M. Schillig, 'The EU Resolution toolbox', in M. Haentjens and B. Wessels (eds.), Research Handbook on Crisis Management in the Banking Sector (Edward Elgar Publishing, 2015).
} 
For the bail-in tool to be a credible resolution tool, there must exist sufficient liabilities at the point when a resolution authority determines that an institution meets the conditions for resolution and that writing down or converting the debt of an institution would be in line with the objectives of resolution. ${ }^{18}$

By definition, this will depend on the systemic importance of different institutions. Depending on their risk profile, complexity, size, interconnectedness etc., all banks need to maintain (subject to on-going verification by authorities), a percentage of their liabilities in the form of shares, contingent capital and other unsecured liabilities not explicitly excluded from bail-in.

The exact degree of burden-sharing would depend on the bank in question, the amount of losses that would need to be covered, and the wider economic situation. Bail-in would a priori apply to any liability which is not excluded. In exceptional circumstances and where strictly necessary for financial stability, bail in could be discontinued upon reaching $8 \%$ of total liabilities including capital. After this, resolution funds could assume $5 \%$ of the losses. Public funds could either be provided to give limited backup support to the resolution fund at this point or, in extraordinary circumstances, directly to cover losses after the $5 \%$ contribution from the resolution fund and if bail-in has reached eligible deposits. Only in the scenario of severe systemic stress could public funds replace the resolution fund immediately, but only after bail-in up to $8 \%$ of total liabilities.

\section{Resolution and state aid rules}

As already mentioned, the BRRD and SRM aim to avoid as far as possible the use of taxpayers' money during a bank failure. However, they do not prohibit the use of public funds to finance bank resolution notably in systemic crises. The BRRD and SRM do not prejudice the application of the EU state aid rules, provided of course that the assistance which is given to a bank can be classified as state aid.

The 2013 Banking Communication requires that burden-sharing is enforced in all state aid granted to banks, not just in the case of resolution. It also defines the sequence for bailingin, as later laid down in the BRRD and the SRM Regulation. Banks that ask for state aid should undertake all measures to minimise the amount of public money they need to stay afloat. To that end, a bank with a capital shortfall should first carry out all possible capital raising measures by private means before it can resort to any public support. The Member State concerned and the bank have to set up a capital raising plan which has to be endorsed by the competent supervisory authority. Capital raising measures can, for example, include rights issues, a voluntary conversion of subordinated debt instruments into equity on the basis of a risk-related incentive, liability management exercises which should in principle be $100 \%$ capital generating, sales of capital-generating assets and portfolios, securitisation of portfolios in order to generate capital from non-core activities, or an earnings retention. ${ }^{19}$

Only if those measures are not sufficient to fill the capital shortfall, then shareholders and subordinated creditors will be required to contribute.

\footnotetext{
${ }^{18}$ Ibid.

${ }^{19}$ C. Quigley QC, European State Aid Law and Policy.
} 
In cases where the capital ratio of the bank remains above the EU regulatory minimum, the bank should normally be able to restore the capital position on its own, in particular through the capital raising measures mentioned above. If there are no other possibilities, including any other supervisory action such as early intervention measures or other remedial actions to overcome the shortfall defined by the supervisory authority, then subordinated debt must be converted into equity before state aid is granted.

In cases where the bank no longer meets the minimum regulatory capital requirements, subordinated debt must be converted or written down before state aid is granted.

Under the Banking Communication, the Commission can make an exception to the burden sharing requirements only when the implementation of writing down or conversion of subordinated creditors would lead to disproportionate results or would endanger financial stability. This could cover cases where the aid amount to be received is small in comparison to a bank's risk weighted assets and the original capital shortfall has been significantly reduced through capital raising measures. The Commission decides about the application of the exception on a case by case basis. ${ }^{20}$

\section{When does resolution create a state aid situation?}

Given that both the SRM and BRRD stipulate that the SRF and the NRFs will use resources which are contributed by banks themselves over a period of 10 years, it is at first glance rather surprising that resolution is subject to state aid scrutiny. Therefore, it is reasonable to ask when the resolution of a bank creates a state aid situation.

At this stage, the simple but not very precise or comprehensive answer is that there is a state aid situation when state resources are used in the resolution. As explained in more detail below, the concept of state resources covers not just funds which come from the budget of a public authority, but also private funds over which the state can exercise control. $^{21}$

This implies that if banks themselves or their associations decide to intervene in a fully private arrangement to rescue a failing bank, there is no state aid. In this case, funds are contributed voluntarily by the private sector and without any interference from the state.

Otherwise, private resources, which flow through an entity which is controlled by the state, become state resources regardless of their origin. This would be the case with NRFs, despite the fact that they are capitalised through contributions by the banks themselves. The national resolution authorities manage these funds and decide when and how they are used. In this way, they seek to meet public policy objectives. If state resources are used and state aid is granted, the resolution has to be state-aid compliant. The responsible resolution authority has to decide whether to liquidate a failing bank under applicable insolvency

\footnotetext{
${ }^{20}$ Europa Rapid Press Release, State aid: Commission adapts crisis rules for banks - frequently asked questions, 15 October 2013.

${ }^{21}$ The landmark judgments on the concept of state resources are C-379/98, PreussenElektra; C-482/99, France v Commission; C-677/11, Doux Élevage; C-262/12, Association Vent De Colère.
} 
procedures or whether it is in the public interest to resolve the bank under EU state aid rules and the SRM/BRRD requirements.

But even if state resources are used, there may still not be state aid if a Member State chooses to intervene in a bank in the same way as a private investor would do. Then such an intervention would not constitute state aid because it does not confer any advantage that is not available under normal market conditions. For example, a loan can be granted at market prices fully reflecting the risk assumed by the public investor. Or, the state purchases assets at market prices.

Conversely, if assets are transferred at above market prices or at book value to a bad bank, then they confer an advantage, they constitute state aid and can only be implemented if the bank is put into resolution, in compliance with state aid rules and relevant SRM/BRRD requirements.

\section{The practice of the Commission in applying state aid rules to resolved banks}

The Commission has assessed the resolution of several banks across the European Union. Its assessment covered both individual resolutions and schemes establishing a framework for the possible resolution of several banks. A sample of the most recent cases includes the following: SA.33001, Danish winding up scheme for credit institutions ${ }^{22}$; SA.34255, restructuring of CAM and Banco CAM, Spain ${ }^{23}$; SA.37425, credit unions orderly liquidation scheme, Poland ${ }^{24}$; SA.40441, MKB, Hungary; SA.36123, Banif, Portugal ${ }^{25}$; SA.41924, Banca Romagna Cooperativa, Italy ${ }^{26}$; SA.39543, Banca delle Marche, Italy ${ }^{27}$; SA.41134, Banca Popolare dell'Etruria e del Lazio, Italy ${ }^{28}$; SA.41925, Cassa di Risparmio di Ferrara, Italy ${ }^{29}$; SA.43547, Cassa di Risparmio della Provincia di Chieti, Italy ${ }^{30}$.

The resolution plans in the last four cases were approved by the Commission on 22 November $2015 .^{31}$ The Italian resolution fund intervened to ensure the orderly resolution of the four banks in order to preserve financial stability.

The four banks, with combined market share of about $1 \%$ in Italy, were put into resolution by a decision of the Bank of Italy. The Commission found that the use of the national resolution fund minimised the need for state aid and limited distortions of competition. Customer deposits remained fully protected. ${ }^{32}$

\footnotetext{
${ }^{22}$ Denmark - SA.33001.

${ }^{23}$ Spain - SA.34255.

${ }^{24}$ Poland - SA. 37425.

${ }^{25}$ Portugal - SA.40441.

${ }^{26}$ Italy - SA.41924.

${ }^{27}$ Italy - SA.39543.

${ }^{28}$ Italy - SA.41134.

${ }^{29}$ Italy - SA.41925.

${ }^{30}$ Italy - SA.43547.

${ }^{31}$ Europa Rapid Press Release, State aid: Commission approves resolution plans for four small Italian banks Banca Marche, Banca Etruria, Carife and Carichieti, 22 November 2015.

32 Ibid.
} 
The resolution plans foresaw the immediate creation and capitalisation of four temporary bridge banks. All of the banks' assets and liabilities, except remaining equity and subordinated debt, would be transferred to these bridge banks. This transfer would stabilise the activities that were formerly carried out by the banks and also protect depositors. The bridge banks would be sold in an open and non-discriminatory process with the aim to maximise the sales price.

Italy's resolution fund would provide EUR 3.6 billion to the bridge banks, both to cover the negative difference between the transferred assets and liabilities and to capitalise the bridge banks. This would be financed by contributions from the Italian banking sector to the resolution fund.

The measures also included a transfer of impaired assets from the bridge banks to a newly created Asset Management Vehicle. The resolution fund would guarantee this impaired asset measure. The benefit of the guarantee was quantified at approximately $€ 400$ million in additional support from the resolution fund.

The interventions from the resolution fund qualified as state aid because the fund was considered to be an agency of the state carrying out public policy.

The Commission found that the resolution measures were in line with the overarching objective of preserving financial stability, as required by the 2013 Banking Communication. Existing shareholders and subordinated debt holders contributed to the costs, reducing the need for the intervention by the resolution fund in line with burden-sharing principles. In order to limit distortions of competition, the bridge banks would only exist for a limited amount of a time. The Commission also committed to assess under EU state aid rules the viability of the entities resulting from the sale of the bridge banks. ${ }^{33}$

\section{Case study: SA.39451, Banca Tercas, Italy}

Unlike in the case of the four Italian banks mentioned earlier, the Commission decided on 23 December 2015 that the resolution of Banca Tercas, another Italian bank, contained incompatible state aid. ${ }^{34}$ In this case the public support came from the Italian mandatory deposit guarantee scheme.

Banca Tercas is a small Italian bank with a market share of about $0.1 \%$ of total banking assets in Italy. In July 2014, the Italian mandatory deposit guarantee scheme Fondo Interbancario di Tutela dei Depositi (FITD) intervened in favour of Banca Tercas in order to cover the losses of the bank and support its sale to Banca Popolare di Bari. The Commission found that the FITD acted on behalf of the Italian state and that the measures were not in line with EU state aid rules.

In July 2014, the FITD with the approval of the Bank of Italy, provided approximately $€ 300$ million in support (through capital injections and guarantees) to Banca Tercas for its

\footnotetext{
33 Ibid.

${ }^{34}$ Europa Rapid Press Release, State aid: Commission finds Italy provided incompatible state aid to Banca Tercas and welcomes plans of private funds to step in, 23 December 2015.
} 
acquisition by Banca Popolare di Bari. The Commission opened an in-depth probe into the support measures in February 2015. In December 2015 it concluded that the Banca Tercas received incompatible state aid. The aid was not in compliance with the 2013 Banking Communication, because:

1. Italy did not present a restructuring plan, so the Commission was not able to evaluate if the aided entity could return to long-term viability.

2. Although Banca Tercas' existing shareholders were fully written down at the time, subordinated creditors did not make any contribution to the cost of restructuring, as is required under burden-sharing principles.

3. No measures were implemented that would have sufficiently limited the distortion of competition created by the aid. ${ }^{35}$

Deposit guarantee schemes are mandatory under EU law to ensure that covered deposits are paid out when a bank is liquidated and exits the market, in which case there are no state aid issues. However, in the present case, the FITD intervened beyond this pay-out function to depositors by granting support to Banca Tercas which was in financial difficulty. Although the funds of FITD came from private sources [banks], if they came under public control before they were granted to Banca Tercas, and the decision to do so was attributed to the state. However, even if funds are state aid they can still be used to support an ailing bank, provided that the measures comply with the conditions of EU state aid rules and the BRRD.

The FITD support in favour of Banca Tercas included the following measures:

1. A non-repayable contribution of EUR 265 million to cover the negative equity of Tercas.

2. A guarantee of EUR 35 million (for three years) to cover the credit risk associated with certain exposures of Tercas.

3. A guarantee of EUR 30 million to cover part of the possible additional cost and losses (of EUR 60 million) associated with the tax treatment of the non-repayable contribution of EUR 265 million.

4. The Commission also believed that Banca Tercas benefitted from indirect state aid because, under Italian law, FITD's support interventions are not subject to normal corporate taxes. $^{36}$

\section{The views of the Commission on the use of state resources}

According to recital 3 of Directive 2014/4937, "measures [carried out by DGSs] should always comply with the State aid rules." According to recital 16 "it should also be possible, where permitted under national law, for a DGS to go beyond a pure reimbursement function and to use the available financial means in order to prevent the failure of a credit institution with a view to avoiding the costs of reimbursing depositors and other adverse impacts. Those measures should, however, be carried out within a clearly defined framework and should in any event comply with State aid rules". Point 63 of the 2013 Banking Communication states that, "the use of [deposit guarantee funds] or similar funds to assist in the restructuring of credit institutions may constitute State aid. Whilst the funds in question may derive from the private sector, they may constitute aid to the extent that they

\footnotetext{
35 Ibid.

${ }^{36}$ Ibid.

${ }^{37}$ Directive 2014/49/EU of the European Parliament and of the Council of 16 April 2014 on deposit guarantee schemes, [2014] OJ L 173/149.
} 
come within the control of the State and the decision as to the funds' application is imputable to the State".

"44) The Commission also points out that statutory DGSs are extremely likely to grant State aid when they intervene to prevent the failure of a credit institution, given that they act under a public mandate of the Member State and remain under the control of the public authority."

\section{Imputability to the state}

"45) The Court of Justice has repeatedly confirmed that all financial means by which the public authorities actually support undertakings fall under State aid control, irrespective of whether those means are permanent assets of the public sector. Compulsory contributions that are mandatory by and managed and apportioned in accordance with the law or other public rules imply a transfer of State resources, even if not administered by the public authorities. The mere fact that resources are financed in part by private contributions is not sufficient to rule out the public character of those resources since the relevant factor is not the direct origin of the resources but the degree of intervention of the public authority within the definition of the measure and its method of financing."

"46) Moreover, as the Court of Justice pointed out in Ladbroke [C-83/98 P, France v Ladbroke Racing and Commission], in Stardust Marine [C-482/99, France v Commission] and in Doux Élevage [C-677/11, Doux Élevage and Coopérative agricole UKL-ARREE], resources that remain under public control and are therefore available to the public authorities, constitute State resources."

"47) In Doux Élevage, the Court of Justice noted that in the particular case of a trade organisation, whose resources were raised by levies made mandatory by the State, the public authorities had not received powers to actually use the resources to support particular undertakings. The trade organisation had set its objectives itself, while the State would only control the validity and lawfulness of the trade organisation's levying of contributions. In particular, the Court of Justice pointed out in Doux Élevage that the mandatory nature of the levies was in that case not "dependent upon the pursuit of political objectives which are specific, fixed and defined by the public authorities".

"48) The Court of Justice has also clarified in Stardust Marine that imputability to the State of an aid measure taken by a prima facie independent body (for instance, a public undertaking) can be inferred from a set of indicators arising from the circumstances of the case, such as the fact that, apart from factors of an organic nature which link it to the State, the body in question cannot take the contested decision without taking into account the requirements or directives of the public authorities before taking the decision allegedly involving State aid. Other indicators might, in certain circumstances, be relevant in concluding that an aid measure taken by a public undertaking is imputable to the State. [see for example the reference to "supervision by public authorities" in case T-387/11 Nitrogénmúvek Vegyipari Zrt. v Commission]. Similarly, the fact that private persons participate in the running of an entity is not sufficient to exclude imputability to the State of the interventions at issue." 
“49) In the Austrian Green Electricity Act judgment of December 2014, the General Court found that ... the green electricity aid mechanism and the partial exemption of energyintensive users from the financing of green electricity [to be] imputable to the State [T251/11 Austria v Commission (Austrian Green Electricity Act)]. The fact that they were established by law was held sufficient to conclude to such imputability."

“50) In the case at issue, the FITD's interventions in bank restructuring and resolution are discretionary when taken at a Member State's level - in contrast to interventions in liquidation cases, which are mandated by Directive 2014/49 - and fulfil a public policy mandate laid down in Italian law at the discretion of the State."

"53) Thus, the FITD's support interventions in bank restructuring and resolution follow the public policy mandate of depositor protection under the control of Member State authorities, but that instrument is in addition to and not the same as the obligatory function laid down in Union law (Directive 2014/49) which is to pay out covered depositors in the case of liquidation."

"54) The interventions of the FITD to prevent the failure of one of its member banks follow a public mandate of the Member State and ... the Statutes of the FITD must be approved by the Bank of Italy."

"55) Moreover, the Italian authorities appear to constantly control whether the use of the FITD resources is consistent with its specific public policy mandate and to have at least codecided with FITD to use the latter's resources in favour of Tercas."

"60) The Commission is of the opinion that, contrary to the elements invoked by the Court of Justice in Doux Élevage, ... the FITD remained under constant public control, which was effectively performed, over objectives that are specific, fixed and defined by the public authorities, going beyond a mere formal control of the validity and lawfulness of FITD's behaviour."

"61) The Commission considers that those elements are indicators showing that the FITD's interventions in favour of Tercas constitute State resources and are imputable to the State."

\section{The incompatibility of the aid with the internal market}

“90) ... there are no or very insufficient elements showing that:

1. The implemented interventions are appropriate to achieve the objective of ensuring the long-term viability of Tercas. In that respect the Commission notes that it has not received a restructuring plan of Tercas".

2. Appropriate measures have been taken to ensure that the aid is proportionate, i.e. limited to the minimum amount necessary to achieve their objective. In particular there should have been an adequate "burden-sharing" of restructuring costs by those who invested in the bank, such as subordinated creditors, in compliance with the 2013 Banking Communication.

3. The interventions must be appropriately remunerated in line with the requirements laid down in the Crisis Communications. As matter of fact, there seems to have been no 
payment or other kind of significant contribution in consideration for the recapitalisation and guarantee interventions.

4. The costs of restructuring Tercas have to be limited to the minimum necessary. Sufficient measures have been taken to limit distortions of competition, calibrated in such a way as to approximate as much as possible the market situation which would have materialised if Tercas has exited the market without aid."

In another similar case, also involving an Italian bank - Banca Romagna Cooperativa - the Commission noted in its decision SA.41924, that in addition, and despite the fact that at that time [July 2015] Italy had not yet transposed the BRRD into national law, the Commission had to assess whether the aid measure in question violated "indissolubly linked provisions" of the BRRD. According to the Commission, "79) that obligation is in line with the jurisprudence of the Union Courts, which have consistently held "that those aspects of aid which contravene specific provisions of the Treaty other than [Articles 107 and 108 TFEU] may be so indissolubly linked to the object of the aid that it is impossible to evaluate them separately to that their effect on the compatibility or incompatibility of the aid viewed as a whole must therefore of necessity be determined in the light of the procedure prescribed in [Article108]".

"80) To ascertain whether a violation of a provision of Union law is indissolubly linked to the object of the aid, a relation of necessity has to be established. It means that the State aid measure has to be connected with a national measure in a way that necessarily breaches a specific provision of Union law which is relevant for the compatibility analysis under paragraphs 2 and 3 of Article 107 TFEU. 81) The Commission has not identified BRRD provisions which would be indissolubly linked to the specific aid measure under examination. 82) This is without prejudice to the prerogative of the Commission to initiate infringement procedures against a Member State for breach of Union Law, including breach of BRRD provisions." In this case, the aid for the partial liquidation and sale of the remaining assets of the bank was found to be compatible with the internal market.

In summary, there is little doubt that when NRFs or national deposit guarantee schemes are mobilised to bail out banks, they use state resources and their decisions can be imputed or attributed to the state. The argumentation of the Commission, as exemplified by the Banca Tercas case, is convincing.

There is no state aid when the resolution is fully funded by private resources or when a national deposit guarantee scheme limits its intervention only to protecting covered deposits [i.e. up to EUR 100,000]. The use of such schemes for purposes that go beyond protecting covered deposits, even though it is legally possible, will in all likelihood constitute state aid.

However, for the Eurozone countries, as of 1 January 2016, the SRF and the SRB replace the NRFs and the national resolution authorities. The SRB is a "Union agency" with its own legal personality [Article 42 of the SRB Regulation]. Article 107(1) TFEU applies to Member States or state resources. The SRB is not a Member State, nor is it a public authority that comes under the control of any Member State. Therefore, the next section examines why and how state aid rules may apply to the SRF. 


\section{The SRB, the SRF and state aid}

What needs to be clarified at the outset is whether the SRB could in principle be subject to state aid discipline. As mentioned above, the SRB is a Union agency. Article 47 of the SRB Regulation stipulates that the SRB acts independently and that its Chair, Vice-Chair and its four permanent members also act independently and take no instruction from any Member State. The other members of the SRB are appointed by Member States, one per Member State. This means that at present the SRB has six permanent members plus 19 members representing national resolution authorities, making 25 in total.

The Regulation provides that the SRB decides by consensus or simple majority. It is conceivable that the members appointed by Member States outvote the permanent members. But, it is rather unlikely that 13 Member States will agree to take a position contrary to that of the other six Member States. At any rate, it cannot be presumed that in all cases the SRB will be acting to further the interests or policy objectives of any particular Member State.

What is perhaps surprising is that despite the fact the SRB Regulation establishes the SRB as an independent EU agency, it still subjects it to state aid control. ${ }^{38}$ Article 19 of the Regulation lays down a detailed procedure that has to be followed not only when the resolution actions of the SRB contain state aid [i.e. use of state resources proper through the involvement of a national authority] but also when the funding comes solely from the SRF.

Article 19 provides the following:

1. Where resolution action involves the granting of state aid or of Fund aid, the adoption of the resolution scheme shall not take place until the Commission has adopted a positive or conditional decision concerning the compatibility of the aid with the internal market. [It should be noted that the Regulation creates a new funding category, that of "Fund aid", just to make sure that it is well understood that money from the SRF also falls within the scope of Article 107(1) TFEU.]

2. The Member State or Member States concerned must notify the envisaged measures to the Commission under Article 108(3) TFEU.

3. When the resolution action involves the use of the Fund, the SRB must notify it to the Commission. The Commission decides on the compatibility of the use of the Fund with the internal market. Its decision is addressed to the Board and to the relevant national resolution authorities. That decision may lay down obligations on the beneficiary, the Board, or the national resolution authorities.

4. If there is no compliance with the Commission decision, the Commission can issue a decision to the national resolution authority requiring recovery of the misused amounts. Recovered Fund aid must be paid back to the Board.

It is clear that the SRB must comply with state aid rules, regardless of whether it is a European agency or not, regardless of whether the resources used are contributed by the

${ }^{38}$ M. Schillig, 'The EU Resolution toolbox'. Ibid. 
banks themselves and regardless of whether the support is formally classified as state aid or Fund aid. Moreover, Article 44 of the SRB Regulation imposes an explicit obligation on the SRB to act in conformity with EU law, in general, and Commission decisions, in particular.

\section{Assessment}

Although the BRRD and the SRM make the use of state aid less likely because they bail in shareholders and creditors before banks are bailed out with public funds, they still require that decisions of the national resolution authorities and of the SRB are compliant with state aid rules. This means that banks in the Eurozone and outside the Eurozone will be treated in the same way. Application of state aid rules and, by extension, subjecting resolution decisions to the scrutiny of the Commission will ensure that the competitive field will be level and fair not only when banks prosper but also when they exit the market or restructure. Given that actions under the SRM have to be consistent with actions under the BRRD and, by implications, actions under national resolution regimes, there should be greater uniformity across the whole of the EU in resolving or restructuring banks. This in itself should allay the fears of the UK and perhaps other non-Eurozone countries that deeper integration in the Eurozone will somehow be to their disadvantage.

Indeed one of the requests of the UK in its negotiations of a new relationship with the EU is that deeper integration in the Eurozone does not disadvantage the non-euro countries. ${ }^{39}$ The SRM and BRRD ensure that, at least as far as state aid to banks is concerned, restructuring and resolution will be carried out on the basis of the same rules and will be approved by the same institution - the Commission - which should bring about consistency in how the rules are applied.

Ironically, if there is a disadvantage it will be to the detriment of banks in the Eurozone rather than the other way around. This is because the procedure involving the SRB is more cumbersome as any decision will have to be approved by many more actors. In addition, the members of the SRB may have distinct views and, despite their independence, these views may be coloured by their national origin and responsibilities in the national resolution mechanisms.

Although there is little doubt that state aid discipline ensures equal treatment of all EU banks and minimises distortions to competition across the internal EU market, at a more theoretical level the question remains whether the SRB should have been empowered to apply state aid rules without further involvement of the Commission. There are credible arguments both in favour and against.

On the one hand, state aid rules are well understood. This suggests that the involvement of the Commission is not necessary. In 2004, the enforcement of Article 101(1\&3) TFEU was decentralised. Perhaps the time has come to centralise the enforcement of restructuring and resolution of banks which are funded by resources managed at EU level without any further need for Commission approval.

\footnotetext{
${ }^{39}$ For an analysis of the requests of the UK and the initial response as defined in the position paper prepared by the President of the European Council, see P. Nicolaides, R. Nedelescu, J. Hornik and G. Watfe, The New Deal with the United Kingdom: The Downside of Flexibility, College of Europe, BEEP no. 38, February 2016.
} 
On the other hand, restructuring, as well as resolution, requires discretion and judgment. Such discretion can be exercised consistently only if it is exercised by the same institution. This suggests that the involvement of the Commission is indispensable. In the end, only the future will tell whether the extra uniformity in the application of state aid rules brought about by the involvement of the Commission is worth the extra administrative bureaucracy.

\section{Conclusions}

The aim of the BRRD and SRM is twofold: to ensure that 1) ailing banks close down in an orderly fashion or that are properly restructured if they can become viable again and that 2) the use of public resources is minimised. The first aim restores the health of financial markets while the second aim protects the health of public budgets. Both of them make the use of state aid less likely. Both of them protect small depositors and prevent systematic failure. And, therefore, both of them lay the foundations for the long-term recovery of the European economy.

However, the SRM has added an extra layer of bureaucracy and complexity. In addition, to the involvement of national authorities and the Commission, in its capacity as the institution that assesses the compatibility of aid, decisions have to be taken collectively by the SRB too. The collective nature of such decisions suggests that the assessment of the Commission is less necessary or at least that the decisions should be subject to a lighter scrutiny by the Commission. 